\title{
マルチフォントの自動関数化における 接合点の多段階抽出法
}

\author{
非会員 堀 内 隆 彦 (筑波大) \\ 非会員大 瀧 保 広 (筑波大) \\ 正員寅市和男 (筑波大)
}

\section{On Method of Extracting Joint Points for Generating Function-Fonts of Multi-Symbols}

Takahiko Horiuchi, Non-member, Yasuhiro Ohtaki, Non-member, Kazuo Toraichi, Member (University of Tsukuba)

In the previous research, the authors proposed a method to generate high quality function-fonts for brush-written characters automatically. This method extracts sharp edges of boundary lines, so-called joint points, and approximates the boundary line between each adjacent joint points using piecewise polynomials. As the next step, we applyed the previous method for printed characters and figures. We find that they have another rules of quality and that the previous method cannot be adopted to these fonts. This paper aims to make clear how joint points should be determined for many kinds of fonts and to present a multi-stage algorithm to extract them exactly. The performance of the present method is verified by some experiments.

キーワード：フォント，関数近似，接合点

\section{1. まえがき}

高品質な文字と図表が混在したドキュメントを，パ ーソナルコンピュータを用いて作成するために，デス クトップパブリッシング（DTP）システムの研究が 盛んに行われている。DTPシステムに要求される基 本要件は，ューザインタフェースがユーザにわかりや すいこと，種々のフォント（毛筆体，活字体など）な らびに図表（エンブレムやマークなど）が効率的に取 り扱えることなどである。

著者らは, 先行研究に扔いて, 後者の基本要件に着 目した。手紙を心のこもった毛筆体で書きたいという 動機に基づいて, 種々のフォントのなかから毛筆体を 取り上げて，滑らかな高品質フォントを自動的に関数 化する手法を提案した(1)。その手法は，(1)フォント が自動的に関数化されること，(2)フォントの品監が 高いこと，(3)フォントのデー多量が少ないことの 3
条件の下に考案され，毛筆書体に対して有効な結果を 得た。

しかし，同手法をDTPの基本要件である種々のフ オントや図表に適用した結果は, 再生結果が必ずしも 原画像の品質を再現できないことを示した。特に，円 弧と直線のつなぎめなどが骬らかに近似されてしま い, 図形などが本来もっているメリハリを失う結果と なった。このような品費劣化の原因の一つとして，活 字体や図表などは，毛筆体用の手法によって抽出され る鋭角な輸郭線部分である「接合点」のほかに，輪郭 線の種類が変わる「接合点」をもつためと考えられ る。

本論文では，図表・活字体などのマルチフォントに 対して，的確に接合点を抽出するアルゴリズムを提案 する。この目標を達成するために，種々の活字体や図 表のもつ接合点の特徽を分析する。その分析結果に基 づいて, 輪郭線の接合点を多段階抽出法によって抽出 
する。

本論文で提案する多段階抽出法は, 第 1 段階て離散 曲率によって接合点を抽出し, 第 2 段階で翰郭線の近 似関数の曲率によって接合点を追加し，第 3 段階で不 必要な接合点を除去する方法である。本手法を，毛筆 書体，活字体，図形，表に適用することにより，性能 の検討を行っている。

第 2 章では文献 ( 1 )の手法を活字体・図表などに適 用した場合の問題点を分析する。第 3 章では分析の結 果に基づいて設計された手法が提案される。第 4 章で はその手法を用いた実駼結果を示す。

\section{2. 要求仕様の検討}

本章では，文献(1)の手法を種々の活字体や図表な どに適用したときに生じる閣題点を分析することによ って，種々の活字体や図表などの自動圧縮手法に要求 される具体的な目標を明らかにする。

文献 (1) 法，（1）フォントの作成労力を省くこと， (2) 高品質な文字の取扱いが可能なこと，(3)フォン トのデータ量が少ないことを具体的な目標として, 高 品質な毛筆フォントを，(1)自動的に，(2)品質を保 持したまま（3）少ないデー夕量へ圧縮する手法を提 案した。

図1（a）注，文献（1）の手法を毛筆体に適用した際 の, 原文字と再生文字を例示している。文献 (1)の手 法を，種々の活字体や図表に適用した結果は，（b)図 $\zeta(c)$ 図に例示されている。(b)図は文献(1) の手法 を図形に適用した結果を例示して扔り，(c)図は活字 体に適用した結果を例示している。各フォントは，毛 筆体と同様に，自動的に圧縮・再生されている。

しかしながら，(b)図抢よび(c)図に扔いて顕著に 示されているように, 再生結果は, 原画像の品質を再 現しているとはいえない。特に, 円弧と直線, あるい は曲線と直線といった輪郭線の種類の変更点が滑らか に再現され，図形などが本来もっているメり八りを失 う結果となっている。このような品質の劧化の原因の 一つとして，文献(1)の手法によって鋭角な輪郭部分 に抽出さ机る「接合点」の添かに，活字体や図表など は輪郭線の種類が変わる場所に接合点をもつためと考 えられる。実際, 我々が図表を作図するときに, 直線 部分に対しては定規を，円弧部分に対してはコンパス を用いることからも，輪郭線の種類の変更点を明確に 抽出する必要のあることがわかる。種々の活字体や図 表用の接合点抽出手法を構築するために, 画像の品質 を保つ際に着目すべき特徵を, 毛筆体と活字体, 図表 との間で比較・検討する。

電学論C, 113 巻 12 号, 平成 5 年

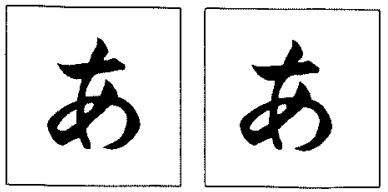

(a)

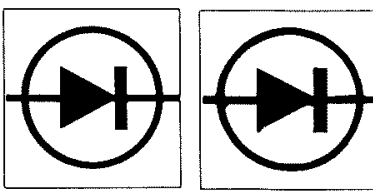

(b)

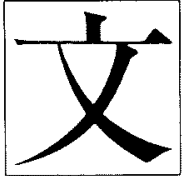

原画像

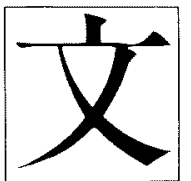

慗生画策 （a）毛筆体，（b）図表，（c）活字

図 1 文献( 1 ) の手法の適用例 Fig. 1. Examples of reconstructed font using Ref. (1).

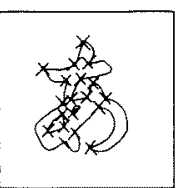

(a)

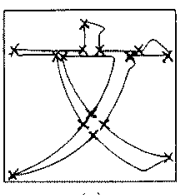

(c)

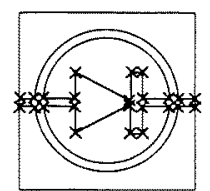

(b) （a）毛篻体，(b) 図表，（c）活字

図 2 接合点 $(x)$ の表示

Fig. 2. Joint points ' $X$ '.

毛筆体の輪郭線の接合点は, 図 2(a)に例示される ように，ストロークが交差する角に生じる。文字の構 成を明確にするために，独立する輪郭線の接合点であ る角の鋭さを再現する必要がある。また，毛筆体の特 徵として「はらい」と呼ばれる筆使いがあり,この際 に「はらい」の先端に生じる鋭角な部分を, 輪郭線の 接合点として鋭角に再現する必要がある。

図表の中には, 図 $2(b) に$ 例示されるように，直 線, 円弧, 自由曲線が漉在して㧍り, 図表の精鋭さを 
表現するためには，図表の输郭線の交点のほかに，そ れぞれ直線や円弧などのつなぎめを輪郭線の接合点と

して再現する必要がある。

活字体の場合も毛筆体と同様に，ストロークの交差 点を輪郭線の接合点として再現する必要がある。ま た，図表と同様に，直線，円弧，曲線の接合点も輪郭 線の接合点として再現する必要がある(図 $2(\mathrm{c})$ )。

輪郭線の接合点に関する考察に基づき, 文献 (1)の 手法では, 接合点はストロークの交差点とはらいの先 端に必ず抽出され，それ以外の場所では毛筆の滑らか さを失ってしまうため抽出する必要がなかった。しか し，図表・活字体に対寸る分析結果加ら，新たに直線， 円弧，曲線のつなぎめに接合点が要求される。

本章では，本手法に要求される具体的な目標の検討 を行った。

\section{3. 接合点の多段階抽出法}

本章では，前章で検討した目標を满たす接合点の抽 出手法が示される。〈3・1〉節では図表などの再現すべ き品質の分析に基づいて，手法の設計方針が検討され る。〈3・2〉節では離散的な曲率に基づく接合点の抽出 手法が示され，〈3・3〉節では輪郭線の近似関数の曲率 に基づく接合点の抽出手法が示される。〈3・4〉節で は，〈3・2〉節招上びく3・3〉節で局所的に求められた接合 点のなかから，大局的に不必要な接合点を除去する手 法が示される。

〈3・1〉設計方針 本節では設計方針が示される。 文献(1)に扔いて，入力さ机た毛筆文字のストロー クの交差点および「はらい」の先端部に生じた接合点 が，離散的な曲率(2)を用いて抽出された。図表や活 字を対象としたとき，輪郭線の接合点の分析に基づ き，ストロークの交差点のほかに，直線，円弧抢よび 自由曲線のつなぎ部分に接合点を正確にとることが 要求される。

本手法は，3段階の多段階抽出によって，図表や活 字に対する接合点を正確に求める。第 1 段階では，ス トロークの交差点を抽出するために，離散的な曲率を 用いて，直角な角点および直線のつなぎめを明らかな 接合点として抽出する。

第 2 段階では，直線，円弧抢よび自由曲線のつなぎ めを抽出する。離散的な曲率を用いると，雑音によっ てつなぎめが抽出されないことがある。そこで，第 1 段階で抽出された隣り合う二つの接合点の間にある輪 郭点列に対して, 適応的な関数近似を行い, 近似関数 の曲率を用いて，直線抒上び円弧のつなぎめを接合点 として抽出する。第 2 段階までに求められた接合点

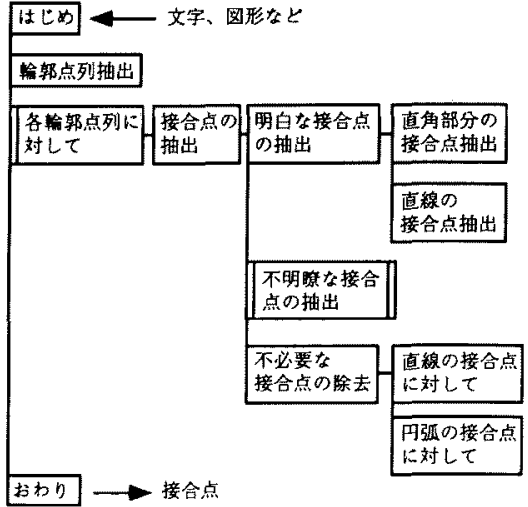

図 3 接合点抽出の手続き

Fig. 3. Procedure of joint point extraction

は，輪郭点列の局所的な変化に基づいて抽出されたも のである。第 3 段階では，第 2 段階までに求められた 接合点から，大局的に不必要と判断される接合点を除 去する。

以上，接合点抽出手法の設計方針として，文字の輪 郭点列加ら多段階抽出に上って接合点を抽出する方法 が定められた。その手順は，図 3 にまとめられる。そ の具体的な手続きは，次節で示される。

〈3.2〉離散的な曲率に基づく接合点の抽出

本節では，離散的な輪郭データに基づき，明らかな 接合点を抽出する手法が示される。

入力される原画像は，二値化されて $256 \times 256$ ドッ トのビットマップの形で蓄えられている。図 4(a) は，活字の原画像を例示している。原画像加ら，8連 結規則で文字の輸郭を追跡し，幾つかの輪郭点列 $\left\{\left(x_{i_{i}}, y_{i_{1}}\right)\right\}_{i_{1}=1}^{n_{1}}$ が抽出される。ただし, 輪郭点数 $n_{1}$ が 8 画素以下のときには, その輪郭点列を取込みの際の 雑音と判断して除去する。

抽出された輪郭点列から，接合点を求める方法を示 す。本手法は，以下の 3 段階からなっている。第 1段 階では離散的曲率に基づいて，直角な角点㧍よび直線 のつなぎめを接合点として求める。第 2 段階では，得 られた接合点間を区分的な関数で近似し，その曲率に 基づいて接合点を追加する。第 3 段階では，大局的に 不必要な接合点を除去する。本節では，第 1 段階につ いて説明する。

第 1 段階では, 離散的な曲率を用いて，直角な角点 および直線の両端点を接合点として抽出する。初めに 直角部分の抽出方法を示す。輪郭点列 $\left\{\left(x_{i_{1}}, y_{i_{1}}\right)\right\}_{i_{1}=1}^{n_{1}}$ 上の 1 点 $P_{i_{1}}\left(x_{i_{1}}, y_{i_{1}}\right)$ から輪郭点列上で $K_{1}$ 個離れた点 
フォント関数化にょける接合点抽出法

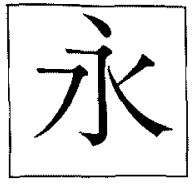

(a)

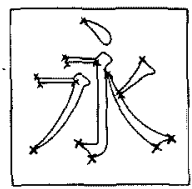

(c)

(a) 原画

(c) 第 2 段眭の捪出結果

(b) 第 1 段階の抽出結果

図 4 接合点の抽出過程

Fig. 4. Process of joint point extraction.

$P_{i_{1}+K_{2}}\left(x_{i_{1}+K_{1}}, y_{i_{1}+K_{2}}\right)$, 点 $P_{i_{1}-K_{1}}\left(x_{i_{1}-K_{1}}, y_{i_{1}-K_{2}}\right)$ を設定

し, 線分 $P_{i 1} P_{i_{1}+K_{1}}$ と線分 $P_{i_{1}} P_{i_{1}-K_{1}}$ のなす角の余弦

$$
P_{i_{1} K_{1}}=a_{i_{1} K_{1}} \cdot b_{i_{1} K_{1}} /\left(\left|a_{i_{1} K_{1}}\right|\left|b_{i_{1} K_{1}}\right|\right)
$$$$
\left(i_{1}=1,2, \cdots, n_{1}\right)
$$

を求める。ただし，

$$
\begin{aligned}
& a_{i_{1} K_{1}}=\left(x_{i_{1}+K_{1}}-x_{i_{1}}, y_{i_{1}+K_{3}}-y_{i_{1}}\right) \\
& b_{i_{1} K_{1}}=\left(x_{i_{1}-K_{1}}-x_{i_{1}}, y_{i_{1}-K_{1}}-y_{i_{1}}\right)
\end{aligned}
$$

とする。ここで, 記号「」はばクトルの内積を表す。 このとき， $P_{i_{1} K_{1}}=0$ である点が存在すれば，その点を 直角の接合点とする。定数 $K_{\mathbf{I}}$ は，実験結果の主観的 評価に基つき $K_{1}=3$ とした。

次に，直線の雨端点の接合点の抽出方法在示す。 $\left\{P_{i_{i} K_{1}}\right\}_{i_{1}=1}^{n_{1}}$ の值を調べて， $P_{i_{1} K_{1}}=-1$ である点が $K_{2}$ 点 以上連続して存在すれ代，更に両側に $K_{1}$ 点ずつ延長 した輪郭点列を直線区間とみなし，その始点と終点を 接合点とする。しきい値 $K_{2}$ は, 実験結果加ら $K_{2}=25$ とした。

以上の手続きを，すべての $i_{1}\left(i_{1}=1,2, \cdots, n_{1}\right) k$ 対し て行うと, 輪郭点列 $\left\{\left(x_{i_{1}}, y_{i_{1}}\right)\right\}_{i_{1}=1}^{n_{1}}$ における直角な角 点㧍よU゙直線区間の両端点が，接合点 $\left\{\left(x_{i_{2}}^{(B)}, y_{i 2}^{(B)}\right)\right\}_{i_{2}=1}^{n_{2}}$ としてすべて求められる。 $n_{2}$ 姑，第 1 段階で求めら れた接合点の総数を表している。

图 4 (b)は，(a)図に以上の手続きを適用して得ら れた，直解の接合点执よび直線区間の雨端点の接合点 を示す。

〈3・3〉近似関数の曲率に基つく接合点の抽出 本節では，輪郭線を関数近似し，その近似関数の曲率 を用いて接合点を追加する手法が示される。
第 2 段階は、三つの過程からなっている。初めに， 任意の接合点間の輪郭点列 $\left\{\left(x_{i_{3}}, y_{i_{3}}\right)\right\}_{i_{3}=1}^{n_{s}}$ を区行的多 項式 ${ }^{(3)}$ を用いて近似する(これを過程 1 と呼ぶ。 は，注目している接合点間の輪郭点列の数示してい る。次に，近似された輪郭の曲率に基づいて，円弧お よび自由曲線の雨端点を接合点として追加する（これ を過程 2 と呼ぶ)。

〔過程 1〕過程 1 では，任意の接合点間の輪郭点 列 $\left\{\left(x_{i_{3}}, y_{i_{3}}\right)\right\}_{i_{3}=1}^{n_{3}}$ を区分的多項式によって近似する。

二次元平面上の曲線を簡便に示す方法として，媒介 変数表現法がある。ここでもをれを採用し， $x$ 方向の 近似曲線は $s_{x}(t), y$ 方向の近似曲線は $s_{y}(t)$ で表現さ れる。媒介変数を輪郭点列の番号と対応させて, $t_{i \mathrm{~s}}=$ $i_{3}-1$ とするとき, $s_{x}(t), s_{y}(t)$ は媒介変数表現された 輪郭点列 $\left\{\left(t_{i 3}, x_{i 3}\right)\right\}_{i 3=1}^{n_{3}},\left\{\left(t_{i 3}, y_{i 3}\right)\right\}_{i 3=1}^{n_{3}}$ に対して, 二次の 区分的多項式を用いた最小二乗近似によって決定され た近似関数である。本諭文で用いている区分的多項烒 は，付録 1 に示される。

区妢的多項式の次元 $n$ が, $n \geqq 3 の$ とき, $s_{x}(t)$, $s_{y}(t)$ の係数 $\left\{c_{x_{t_{4}}}\right\}_{i_{4}=-2}^{n-3},\left\{c_{y_{t 4}}\right\}_{i_{4}=-2}^{n-3}$ は, 二乗淕差 $Q$ :

$$
Q=\sum_{i_{3}=1}^{n_{3}}\left\{s_{x}\left(t_{i_{3}}\right)-x_{i_{3}}\right\}^{2}+\sum_{i_{3}=1}^{n_{3}}\left\{s_{y}\left(t_{i_{3}}\right)-y_{i_{3}}\right\}^{2}
$$

が最小となるように，

$$
\begin{gathered}
\sum_{k=-2}^{n-3} c_{x_{k}}\left\{\sum_{i_{3}=1}^{n_{3}} N_{k, 3}\left(t_{i 3}\right) N_{l, 3}\left(t_{i_{3}}\right)\right\} \\
=\sum_{i_{3}=1}^{n_{3}} x_{i_{3}} N_{l_{3}, 3}\left(t_{i_{3}}\right) \\
\sum_{k=-2}^{n_{3}-3} c_{y_{k}}\left\{\sum_{i_{3}=1}^{n_{3}} N_{k_{3} 3}\left(t_{i 3}\right) N_{l, 3}\left(t_{i_{3}}\right)\right\} \\
=\sum_{i_{3}=1}^{n_{3}} y_{i_{3}} N_{l, 3}\left(t_{i_{3}}\right) \\
(l=-2,-1, \cdots, n-3)
\end{gathered}
$$

によって洪定される。

最小二采近似の収束判定のために，

$$
\epsilon=\max _{0 \leq t_{3} \leq n_{3-1}} \sqrt{\left\{s_{x}\left(t_{i_{3}}\right)-x_{i_{3}}\right\}^{2}+\left\{s_{y}\left(t_{i_{3}}\right)-y_{i_{3}}\right\}^{2}}
$$

を求め, $\epsilon<0.90$ となるまで次元数 $n$ 索増加させる。 ここで, 最大值誤差を用いるのは輪郭点列の山凸を全 点にわたって高精度に近似するためである。

以上, 過程 1 で注, 任意の切断点間の輪郭点列を, 区分的多項式を用いて近似した。

〔過程 2〕以下の過程 2 では, 過程1によって近 似された輪郭線から得られる曲率に基づいて，接合点 が追加される。 
輪郭線の表現に用いられている区分的多項式から曲 率を解析的に求めるための数式を以下に示す。

(性質 1)

〈前 提〉 $s_{x}(t)=\sum_{k=-2}^{n-3} c_{x_{n}} N_{k, 3}(t)$

〈条 件〉 $t \in\left[\xi_{k}, \xi_{k+1}\right]$ において, $s_{x}(t)$ は

$s_{x}(t)=\alpha_{x} t^{2}+\beta_{x} t+\gamma_{x}$

と表せる。ただし，観測区間 $[0, T]$ の節点列を均等 間隔に $\xi_{k}=(T / n) k$ で与える。

〈結 論〉 $t_{0} \in\left(\xi_{k}, \xi_{k+1}\right)$ を用いて, $\left\{\alpha_{x}, \beta_{x}, \gamma_{x}\right\}$ は,

$$
\left.\begin{array}{l}
\alpha_{x}=\left.\frac{d^{2} s_{x}(t)}{d t^{2}}\right|_{t=t_{0}} / 2 \\
\beta_{x}=\left.\frac{d^{2} s_{x}(t)}{d t^{2}}\right|_{t=t_{0}}-2 \alpha_{x} t_{0} \\
\gamma_{x}=s_{x}\left(t_{0}\right)-\left(\alpha_{x} t_{0}-\beta_{x}\right) t_{0}
\end{array}\right\}
$$

で求められる。ここで $(m-1)$ 次の区分的多項式の微 分は, $\xi_{m-3} \leq t \leq \xi_{n+1} に$ 㭁いて，

$$
\begin{aligned}
& \frac{d}{d t}\left\{\sum_{k=-2}^{n-3} c_{x_{k}} N_{k, m}(t)\right\} \\
& =(m-1) \sum_{k=-2}^{n-3} \frac{c_{x_{k}}-c_{x_{k-1}}}{\xi_{k+m-1}-\xi_{k}} N_{k, m-1}(t) \\
& (m=1,2,3, \cdots)
\end{aligned}
$$

で与えられる(4)。

この性質を用いると，各節点区間を二次の区分的多 項式て媒介変数表現することができる。これより，t $\in\left[\xi_{k}, \xi_{k+1}\right] に お い て$,

$$
\begin{aligned}
& s_{x}(t)=\alpha_{x} t^{2}+\beta_{x} t+\gamma_{x} \\
& s_{y}(t)=\alpha_{y} t^{2}+\beta_{y} t+\gamma_{y}
\end{aligned}
$$

と䒾せるとすると，曲線 $x=s_{x}(t), y=s_{y}(t)$ の曲率 $\mathcal{X}$ は,

$$
\begin{aligned}
x(t) & =\frac{s_{x}^{\prime}(t) s_{y}^{\prime \prime}(t)-s_{x}^{\prime \prime}(t) s_{y}^{\prime}(t)}{\left\{s_{x}^{\prime}(t)^{2}+s_{y}^{\prime}(t)^{2}\right\}^{3 / 2}} \\
& =\frac{2\left(\beta_{x} \alpha_{y}-\alpha_{x} \beta_{y}\right)}{\left\{\left(2 \alpha_{x} t+\beta_{x}\right)^{2}+\left(2 \alpha_{y} t+\beta_{y}\right)^{2}\right\}^{3 / 2}}
\end{aligned}
$$

によって表現できる。

以上の手続きで得られる曲率を用いて以下のように 接合点を追加する。

まず，直線の嵲端の接合点を追加する。接合点抽出 の第 1 段階では，嚁散的な曲率を用いて，明らかに直 線である区間の両端に接合点を抽出した。このとき， 直線に画像雑音が少しでもあったときには，直線区間 とはみなされなかった。本手法は，輪郭線の曲率の分 析に基づいて，輪郭近似の精度を緩めることによっ て，画像雑音学除去しながら接合点を抽出する。上記

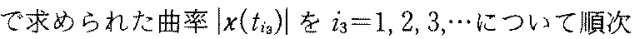
評価する。 $\left|x\left(t_{i_{3}}\right)\right|<K_{3}$ ，加つ媒介変数上での区間て
$K_{4}$ 以上連続しているときに，各区間の曲線は直線と 判定される。直線と判定された区間を $\left(t_{s_{i}}, t_{e_{1}}\right)$ とする と，それぞれの少数点第 1 位を四捨五入したものを

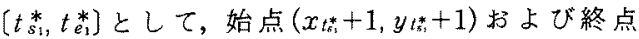
$\left(x_{t_{i}^{*}}^{*}+1, y_{t_{t}^{*}}+1\right)$ が接合点として追加される。直線の 変動を許容するしきい値 $K_{3}$ と直線の長さのしきい值 $K_{4}$ 注，それぞれ $K_{3}=1 / 200, K_{4}=30$ とした。

次に，円弧の両端の接合点を抽出寸る。第 1 段階で 求められた接合点間の曲率 $\left|\boldsymbol{x}\left(t_{i_{3}}\right)\right|$ を $i_{3}=1,2,3, \cdots に つ$ いて順次評洒する。曲率の平均値 $\tilde{x} は$, 着目してい る区間に扔いて，既に評価された曲率の平均值として 順次更新される。評価された区閭の曲率のすべてが $\bar{x} \pm K_{5}$ 以内にあるときは，円弧と判断して評価を続 ける。 価してきた区間 $\left[t_{s_{2}}, t_{e_{2}}\right)$ に打放輪郭線は円弧の候補 として認識される。文の值から，円弧の母体となる円 を算出し，円弧の中心角が $K_{6}$ 以上であるとき，その 輪郭線々円弧であると判定される。区間の両端の座標 の少数点第 1 位を四捨五入したものをそれぞれ〔 $t_{s_{3}}^{*}$ $\left.t_{e_{2}}^{*}\right) と し て$, 始点 $\left(x_{t_{z}}^{*}+1, y_{t_{i}^{*}}+1\right)$, および終点 $\left(x_{t_{i}^{*}}\right.$ $\left.+1, y i_{*}^{*}+1\right)$ が接合点として追加される。

変動の許容幅 $K_{5}$ は, 実験結果より $K_{5}=3 / 400$ と し，円弧を決定するためのしきい值は，直線や自由曲 線まで円弧とみなさないことを考慮した実験結果から $K_{6}=\pi / 2$ とした。

以上の手続きをす心゙ての $i_{3}\left(i_{3}=1,2, \cdots, n_{3}\right)$ に対 して行うと, 輪郭点列 $\left\{\left(x_{i_{3}}, y_{i_{3}}\right)\right\}_{i_{3}=1}^{n_{3}}$ に扔许る直線扔 よび円弧のつなぎめが接合点として求められる。この 手続きを，第 1 段階の抽出で求められたすべての接合 点間に対して行い，接合点 $\left\{\left(x_{i_{2}}^{(B)}, y_{i_{2}}^{(B)}\right)\right\}_{i_{2}=n_{2}+1}^{n_{4}}$ として 追加される。 の総数を表している。

以上の手続きを，図 4(a)の活字体に適用した結果 が(c)図に示される。

〈3.4〉不必要な接合点の除去＼cjkstart本節では，〈3.2〉 節およびく3・3〉節で抽出された接合点列から，大局的 に不必要と判断される接合点を除去する手法が示され る。

第 1 段階および第 2 段階で求められた接合点は，輪 郭点列の局所的な変化に基づいて抽出されたものであ る。従って，画像雑音などの影響によって生じた不要 な接合点が存在する可能性がある。そこで，第 3 段階 では，第2段階までに求められた接合点のなかから， 大局的に不必要な接合点を除去する。接合点の除去は 接合点の両側がともに直線区間である場合とともに円 弧である場合に行われる。 


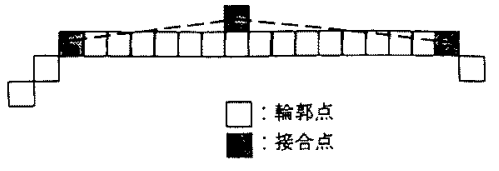

(a) 運続する直線区間

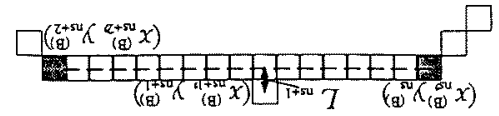

(b) 不必要な接合点の除去

図 5 不必要な接合点の除去（直線区間が 連続する場合)

Fig. 5. Reduction of unnecessary joint points between adjacent straight lines.

初めに，接合点の雨側がともに直線である場合を処 理する。その準備として，第 2 段階までに求められた 接合点 $\left\{\left(x_{i_{2}}^{(B)}, y_{i_{2}}^{(B)}\right)\right\}_{i_{2}=1}^{n_{4}}$ O順序を, 原画像の輪郭点列 $\left\{\left(x_{i_{1}}, y_{i_{1}}\right)\right\}_{i_{1}=1}^{n_{1}}$ の順序に並べ換えておく。図 $5(\mathrm{a})$ に示 されるように，前段階までに抽出された接合点のなか には，その両側がともに直線区間である場合がある。 このとき，その接合点を除去してもデータの品質が十 分保たれるときには，穴の接合点を大局的に不必要な 接合点として除去することとする。除去の方法は, 以 下の手順で行う。

$\left(x_{i_{2}}^{(B)}, y_{i_{2}}^{(B)}\right)$ を $i_{2}=1,2, \cdots$ と順次評洒する。直線区間 が複数連続しているとき, それらの間の接合点列を $\left\{\left(x_{i_{4}}^{(B)}, y_{i_{4}}^{(B)}\right)\right\}_{i_{4}=n_{s}}^{n_{e}}$ で表す。まず, $\left(x_{n_{s}}^{(B)}, y_{n_{s}}^{(B)}\right)$ と $\left(x_{n_{s}+2}^{(B)}\right.$, $\left.y_{n_{s}+2}^{(B)}\right)$ 直線で結び, その間の接合点 $\left(x_{n_{s}+1}^{(B)}, y_{n_{s+1}}^{(B)}\right)$ か らその直線に下ろした垂線の距離 $L_{n_{s}+1}$ が $K_{7}$ 末満の とき, 接合点 $\left(x_{n s+1}^{(B)}, y_{n_{s+1}}^{(B)}\right)$ は, 大局的に不必要な接 合点として除去される(図 $5(b))$ 。

上記の手続きを, $\left(x_{n_{s}}^{\langle B\rangle}, y_{n_{s}}^{(B)}\right)$ と $\left(x_{i_{4}}^{(B)}, y_{i_{i}}^{(B)}\right)\left(i_{4}=n s\right.$ $\left.+2, n_{s}+3, \cdots, n_{e}+1\right)$ との間に対して繰り返し行い, 不必要な接合点 $\left(x_{i_{4}-1}^{(B)}, y_{i^{4}-1}^{(B)}\right)$ を順次除去していく。い ま， $i_{4}$ 番目の接合点に注目していると寸ると，除去の 判定は, $\left\{\left(x_{i 5}^{(B)}, y_{i s}^{(B)}\right)\right\}_{i=1}^{i_{4}-1} n_{s}+1$ 加直線に下ろした垂線 の距離 $\left\{L_{i s}\right\}$ の最大値 $L_{\text {max }}$ を用いて行われる。 $L_{\text {max }}$ $\geq K_{7}$ のを，接合点は除去されず，その区間の評価 を終了する。 $K_{7}$ は，実駼結果より $K_{7}=2$ とした。

次に，接合点の両側がともに円弧である場合につい て処理を行う。図 6 (a) に示されるように, 複数個の 円弧区間が連続していることがある。このとき，間に 存在する接合点を除去してもデータの品質が保たれる ときには，その接合点を除去することとする。除去の 方法は，以下の手順で行う。

電学論C, 113 巻 12 号, 平成 5 年

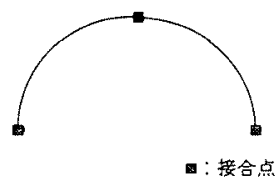

(a) 㖶綍寸る円弧区間

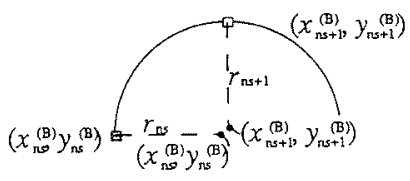

(b) 不必要接含点の除去

図 6 不必要な接合点の除去（円弧区間が 連続する場合)

Fig. 6. Reduction of unnecessary joint points between adjacent arcs.

$\left(x_{i 2}^{(B)}, y_{i}^{(B)}\right)$ を $i_{2}=1,2, \cdots$ と順次評洒する。円弧区間 が複数連続した区間が存在したとき，その間の接合点 列を $\left\{\left(x_{i_{4}}^{(B)}, y_{i_{4}}^{(B)}\right)\right\}_{i_{4}=n_{s}}^{n_{e}}$ で表す。まず, $\left(x_{n_{s}}^{(B)}, y_{n_{s}}^{(B)}\right)$ から 開始する円弧と, $\left(x_{n s+1}^{(B)}, y_{n s+1}^{(B)}\right)$ 加ら開始する円弧に着 目する。両円弧の半径をそれぞれ $\gamma_{n_{s}}, r_{n_{s+1}}$, 中心座 標をそれぞれ $\left(\widehat{x}_{n_{s}}, \widehat{y}_{n_{s}}\right),\left(\widehat{x}_{n_{s+1}}, \widehat{y}_{n_{s+1}}\right)$ とすると,

$$
\left|r_{n_{s+1}}-r_{n_{s}}\right|<K_{s}
$$

かつ

$$
\sqrt{\left(\hat{x}_{n_{s+1}}-\hat{x}_{n_{s}}\right)^{2}+\left(\hat{y}_{n_{s}+1}-\hat{y}_{n s}\right)^{2}}<K_{s}
$$

のとき, 両円弧は単一の円弧とみなされ, $\left(x_{n s+1}^{(B)}\right.$, $\left.y_{n_{s}+1}^{(B)}\right)$ は, 大局的に不必要な接合点として除去される (図6 (b))。

上記の手続きを, $\left(x_{s s}^{(B)}, y_{n_{s}}^{(B)}\right)$ と $\left(x_{24}^{(B)}, y_{i 4}^{(B)}\right)\left(i_{4}=n_{s}\right.$ $\left.+2, n_{s}+3, \cdots, n_{e}+1\right)$ との間に対して繰り返し行い, 不必要な接合点 $\left(x_{2,-1}^{(B)}, y_{1,1}^{(B)}\right)$ を順次除去していく。し きい值 $K_{8}$ 招よび $K_{9}$ は, 実験結果から $K_{8}=1, K_{9}=2$ とした。

以上の評価を，すべての接合点に对して行うことに より，大局的に不必要な接合点が除去される。ここま での手続きによって，すべての接合点が抽出された。

本章で汶，第 2 章で設計した仕様に基づいて，接合 点の抽出手法が設計された。

\section{4. 評洒実 験}

本章では，前章で示した手法を用いて，実際にフォ ントから接合点を抽出し, 各接合点間を近似した結果 を検討することによって，第 2 章で設定した目標が達 せられていることを示す。近似関数として，円弧と判 断された区間は円弧で，その他の区間には文献(1)で 


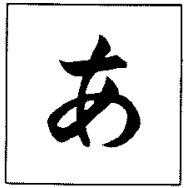

(a)

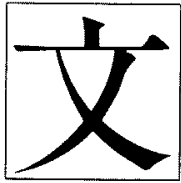

(c)

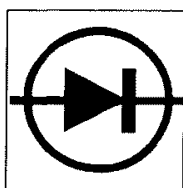

(b)

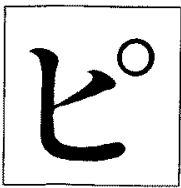

(d)
図 7 再生画像

Fig. 7. Reconstructed images.

用いられている区分的多項式を用いた。

評価のために用いたシステム構成の概要を述べる。

フォントは，イメージスキャナを用いて， $256 \times 256$ ドットの精度で入力される。入力されたフォントか ら, 接合点が多段階抽出され，各接合点間が文献 (1) の手法によって曲線近似される。得られた曲線の係数 からフォントが再生されて出力される。

実験データは，図表としてスキャナの精度で取り込 める 10 種類のシンボルマークが用いられ, 毛筆書体 および活学体の代表例である明朝体としては, 文献 (1)で険証した 1 画から29 画までの58文字が用いら れた。

本章では，図 1 および図 4 に例示されたフォントに 対する実験結果に関して詳細に触れる。

フォントの再生画像を図 7 に示す。図形および活字 体に対する提案手法による再生結果は, 図1で示した 文献（1）の手法によるものに比べて，原画像の品質が 保たれていることがわかる。特に，(b)図に示される 図形の場合は円と直線の接合部抢上び多角形の角部分 に，(c)図に示される活字体の場合は各ストロークの 始点・終点部分に, 違いが顥著に現れている。これは, 文献（1）の手法では抽出されなかった輪郭線の種類の 変更部分が，接合点として正確に得られていることに 起因していると考えられ，結果が第 2 章で設定した仕 様を満たしていることを示している。

また，(a)図に示される毛筆体に対して本手法を適 用した埸合，文献（1）の手法に比べて接合点数が多少 増えるため，毛筆体特有の滑らかさが失われる部分が 生じることもあるが，文献（1）とほほ同等の品質を保 つていることがわかる。

本章では，実験結果を例示し，第 2 章で規定した目 標を達していることを示した。

\section{5.むすひ}

本諭文では，先行論女で示した毛筆体の自動関数化 手法を図表や活字体に適用した場合，原画像の品筫が 維持されないことがあることを述べ，その原因の一つ が接合点の抽出方法にあることを述べた。問題を解决 するために，接合点を多段階的に抽出する手法を新た に提案し，活字体や図表に対して実験を行うことによ って検証を行った。実験の結果, 輪郭線の種颣の変更 部分において，本手法の有効性が影著に現れているこ とを確認した。更に，本手法を毛筆に対しても適用 し，文献（1）の手法を適用した場合と遜色ないことを 示した。

今後の課題は, 図表の特徵を生かせるマルチフォン トの関数化のための一連のシステムを構築することで ある。

本研究の一部は, 文部省科学研究費補助金によるも のである。

(平成 4 年 10 月 14 日受付, 同 5 年 6 月 7 日再受付)

\section{文献}

（1）寅市和男・哭田 䈐・森 亮一：「高品暂文字フォントの自 動价綰」、信学論 (D), J70-D, 1164 (昭 62-6)

(2) L. Davis: "Shape matching using relaxation techniques", IEEE Trans. Pattern Anal. \& Mach. Intell., PAMI-1, 60 (1979)

（3）桜井 明：スプライン関数入門（昭 56）電機大出版展

(4) C. de. Boor: "On calculating with B-splines", J. Approxi. mation Theory, 6, 50 (1972)

（5）寅枋和男：「文字データ人力出力装㯰と入力出力方法」など (国内特䚺 4 件, 国外特許 7 件出䫁中)

\section{付 録}

\section{1. 均等節点の二次の区分的多項式}

近似関数 $s(t)$ は, 各隣り合う境界点間において, 一次または二次のスプライン関数(3)、で表され，かつ 境界点間に扔いて連続な関数である。各境界点間を $[0, T]$ と扝けば，そこでの $s(t)$ は $n$ 次元の関数系

$$
\begin{gathered}
N_{k, 3}(t)=3(T / n)^{-2} \sum_{p=0}^{3} \frac{(-1)^{p}\left(t-\xi_{k+p}\right)_{+}^{2}}{\{p !(3-p) !\}} \\
(k=-2,-1,0,1,2, \cdots, n-3)
\end{gathered}
$$

の線形結合

$$
s(t)=\sum_{k=-2}^{n-3} c_{k} N_{k, 3}(t)
$$

で表される。ここで，

$$
(t-a)_{+}^{2}= \begin{cases}(t-a)^{2} & t>a \\ 0 & t \leq a\end{cases}
$$

である。 


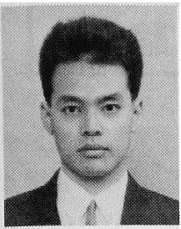

堀内隆 彦 (非会員)

平成 2 年度筑波大学第 3 学群・情報学 類卒業。現在, 同大学大学院博士課程工 学研究科在学中。非線形最適化理論の解 析と認識・思考の数学的モデル化の研究 に従事。日本学術振興会特別研究員。䉓子情報通信学会会 員。

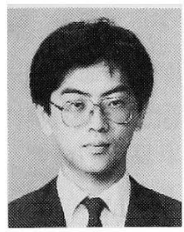

大 瀧 保 広 (非会員)

平成元年度筑波大学第 3 学群・情報学 類卒業。現在, 同大学大学院博士課程工 学研究科在学中。関数近似に基づくマル チメディアの情報圧縮の研究に従事。情 報処理学会会員。

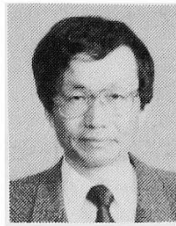

寅市和 男 (正員)

昭和 41 年東京電機大学工学部電子工 学科卒業。 46 年北海道大学大学院博士 課程修了。同年電子技術総合研究所飯島 特別研究室入所。55 年筑波大学電子・情 報工学系助教授を経て, 現在, 同教授。智慧システムとそ の生体工学への応用の研究に従事。平成元年度高柳記念研 究助成。工学博士。IEEE, 電子情報通信学会会員。

\&o \& \& 8 